\title{
Ascertaining evapotranspiration series by the optimized rainfall-runoff model
}

\author{
M. Chlumecky(1), M. Tesar ${ }^{(2)}$ and J. Buchtele(2) \\ (1) Department of computer science, CTU FEE, Technicka 2, 16627 Prague 6, CZ \\ chlumma1@ fel.cvut.cz \\ (2) Institute of hydrodynamics ASC, Pod Patankou 30/5, 16612 Prague 6, CZ \\ miroslav.tesar@iol.cz \\ buchtele@ih.cas.cz
}

\begin{abstract}
Considerable long-term time series of precipitations and air temperature changes were used for modelling the rainfall-runoff process. The time series were also used for the accurate assessment of the evapotranspiration demand of the Czech Elbe River. Random fluctuations of vegetation cover are taken as an indication of deviations in the evapotranspiration. The intention is to appraise such complicated time series as a long-term process. The recently modified software of the conceptual SAC-SMA model firstly enables a prompt simulation and secondly creates the conditions for automatic calibration of this model. This tool provides a separate simulation for each partial time interval with diverse expected values of evapotranspiration. This may be ascertained during the consecutive identification of optimal model parameters. The resulting evapotranspiration values are represented as outputs of modelling; these output values would be difficult to obtain from meteo-observations, e.g. measured data or computed values.
\end{abstract}

Key words: calibration, evapotranspiration, long-term time series, optimization, SAC-SMA model.

\section{Estimación de series de evapotranspiración mediante modelos de lluvia-escorrentía optimizados}

\author{
RESUMEN
}

\begin{abstract}
Se han utilizado series temporales, considerablemente largas, de precipitación y temperatura para el modelado de procesos de precipitación-escorrentía. Las series temporales también se han utilizado para una evaluación precisa de la demanda por evapotranspiración en la cuenca del río Elba en Chequia. Las fluctuaciones temporales de la cubierta de vegetación se han tomado como una indicación de variaciones en la evapotranspiración. La intención es evaluar dichas series temporales complejas como un proceso a largo plazo. El software, recientemente actualizado, del modelo conceptual SAC-SMA, tiene la ventaja de permitir una fácil simulación y reúne las condiciones para el calibrado automático de dicho modelo. Esta herramienta permite una simulación independiente de cada intervalo de tiempo parcial con diversos valores esperados de evapotranspiración. Esto se realiza mediante la identificación consecutiva de parámetros óptimos del modelo. Los valores de evapotranspiración resultante se representan como salidas del modelado. Estos valores serían difíciles de obtener de observaciones meteorológicas, ya sean valores medidos o calculados.
\end{abstract}

Palabras clave: calibrado, evapotranspiración, series temporales a largo plazo, optimización, modelo SACSMA.

\section{Introduction}

Early in the 1960's hydrologists efforts were focused on the development of rainfall-runoff models and processes. These models can be classified as concep- tual or empirical. Both of these approaches may be qualitatively accurate today (Kuczera, 1997). Some of the hydrological variables could be derived directly from observations of the physical phenomena of a basin. There are other variables, which cannot be cal- 
culated in this way because these values can only be measured and/or observed with great difficulty. Therefore, several parameters or phenomena have to be estimated through modelling (Merz, 2006).

There are two approaches on how to calibrate models. The first approach is manual calibration that is based on the experience of the hydrologist who estimates the parameters by trial and error. The second one is an automatic calibration which is based on search algorithms. Outputs of the implemented models can be used for simulations or predictions of hydrological events in certain seasons (Kundzewicz, 2007). The outputs are applied for periods with no historical records available or in order to predict future events. The evapotranspiration is one of the most important hydrological phenomena and it is one of the important constituents of water regimes, namely in the basins with vegetation cover (Leprieur, 2000). The modelling of the rainfall-runoff process is extensively used for the evaluation of these regimes.

The measurement of the evapotranspiration values requires rather an extensive network of precise measuring devices. The measuring set-ups are scarcely realistic for large river basins. If older and longer time series are analysed, values of evapotranspiration are not available at all (Kuczera, 1997). Therefore, in order to obtain values of the evapotranspiration is it is necessary to use a simulation of the rainfall-runoff process.

The simulation needs a substantial amount of input data to reach its realistic values in the framework of runoff modelling. In this context, it might be expected that the actual evapotranspiration, as complicated as it is, is a more uncertain phenomenon in comparison with the monitored precipitation and runoff (Buchtele and Koskova, 2008). Therefore, the assessment of its long-term development is to consider the important task simultaneously with the optimisation of parameters in rainfall-runoff modelling. These circumstances could influence some considerations connected with the implementation of the model.

The aim of this paper is to use and present a method that is based on the rainfall-runoff Sacramento Soil Moisture Accounting (SAC-SMA) model () (Burnash and Ferral, 1973). The method can be helpful to accurately and plausibly ascertain the values of the evapotranspiration for long time series. The approach implemented in this context means that the modelling outputs represent the resulting evapotranspiration ( $\left.\mathrm{ET}_{\text {demand }}\right)$. These values would be difficult to obtain from meteo-observations, e.g. measured or computed values.

\section{Problem framework}

The interactions between the evapotranspiration demand $\left(\mathrm{ET}_{\text {demand }}\right)$ and the soil water content have to be carefully taken into account during a model calibration for long-term time series. This is especially noticeable in hydrological data analyses of time series with lengths of up to 100 years. Three natural phenomena require the evaluation of the input values to clarify the influences on the variability of runoff:

- The periodic and more or less regular climatic oscillation and certain phenomena such as precipitation and evapotranspiration determining the water consumption, while (Beer, 2005) clearly shows the correlation between solar activity and climate variability, and some similar fluctuations have also been pursued quite recently (Buchtele and Tesar, 2013).

- Long-term evolution of vegetation cover, including its possible abrupt changes, i.e. the extraordinary wind disasters and even devastations by insects; those were the events in the central Europe during the second half of 19 century (Vicente-Serrano et al., 2010).

- Significant and flexible geomorphological conditions, or the seemingly random diverse events, caused by increasing agricultural production (Brown, 1997).

In this context, the long-term persistence and oscillations in long time series have been followed by different spheres and periods (Beer, 2005; Hurst, 1951).

The goal of the implementation of the rainfallrunoff process is to reach the precision of modelling outputs including evapotranspiration. Some abrupt or continual unpredictable events might appear in the differences between the monitored and simulated discharge (Wagener et al., 2004). These events may provide the insight into the development of the water regime in various interactions within the basin (changes of forest cover, agricultural production and evapotranspiration, unexpected water storage in lakes or ponds). The development of the water regime can be for instance unexpected water storage, changes of vegetation cover and evapotranspiration, etc.

Note: Sometimes the consequences of vegetation cover changes might be unexpected, as photographically documented (Fig. 1) from the region in central Spain. One of the authors and students from Prague visited the area, where the withdrawals of groundwater influence agricultural irrigation.

The intention to eliminate uncertainties in the water regime due to different fluctuations requires 


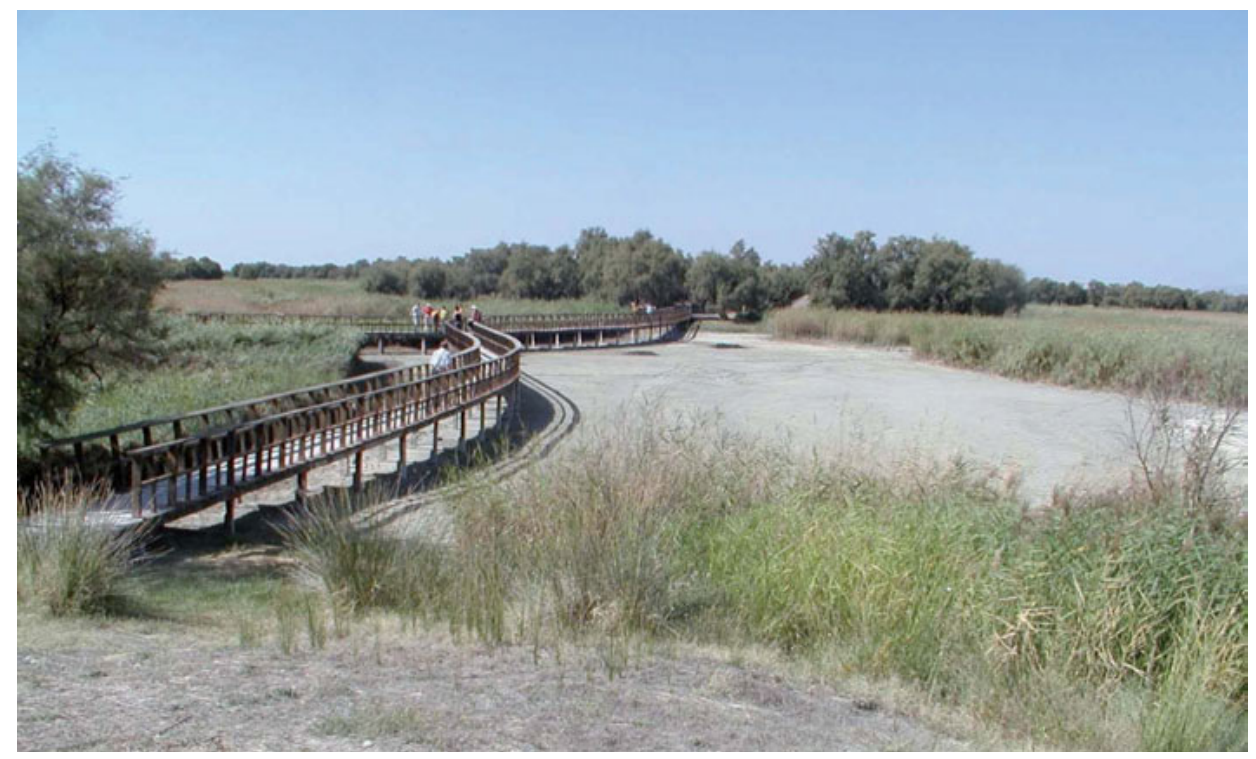

Figure 1. The influence of groundwater withdrawals on agricultural irrigation in central Spain.

Figura 1. La influencia de la extracción de agua subterránea para riego agrícola en la parte central de España.

the evaluation of the naturally appearing ones and the abrupt and seemingly random changes in the basin. The variability of the water system is usually influenced by changes in vegetation cover in the annual cycle (Koren et al., 1999). It is also affected by its development over decades, during which some other natural events may occur, e.g. wind disasters in the forests and other damage.

The changes of vegetation cover and the assessment of the following interactions between the evapotranspiration demand and the sub-surface water storage seem like an important process. This whole issue may appear as important, both at a local and regional scale (Leprieur, 2000).

Agricultural production, e.g. increased crop yield, was considered a dynamic phenomenon of water balance not so long ago (Brown, 1997). The higher variability of evapotranspiration demands requires attention, which is further supported by its connection with the solar radiation that correlates with solar activity (Beer, 2005). Certain fluctuations in Figure 2 and Figure 3 are also evident and should be contemplated.

The length of evaluated time series is meaningful in general circumstances. This enables the observation and assertion of the influences that the vegetation development has on the evapotranspiration demand when daily series are available for several decades,. This could be the significant influence of the runoff. The role of ensuing deforestation has been viewed positively in Great Britain since it provides

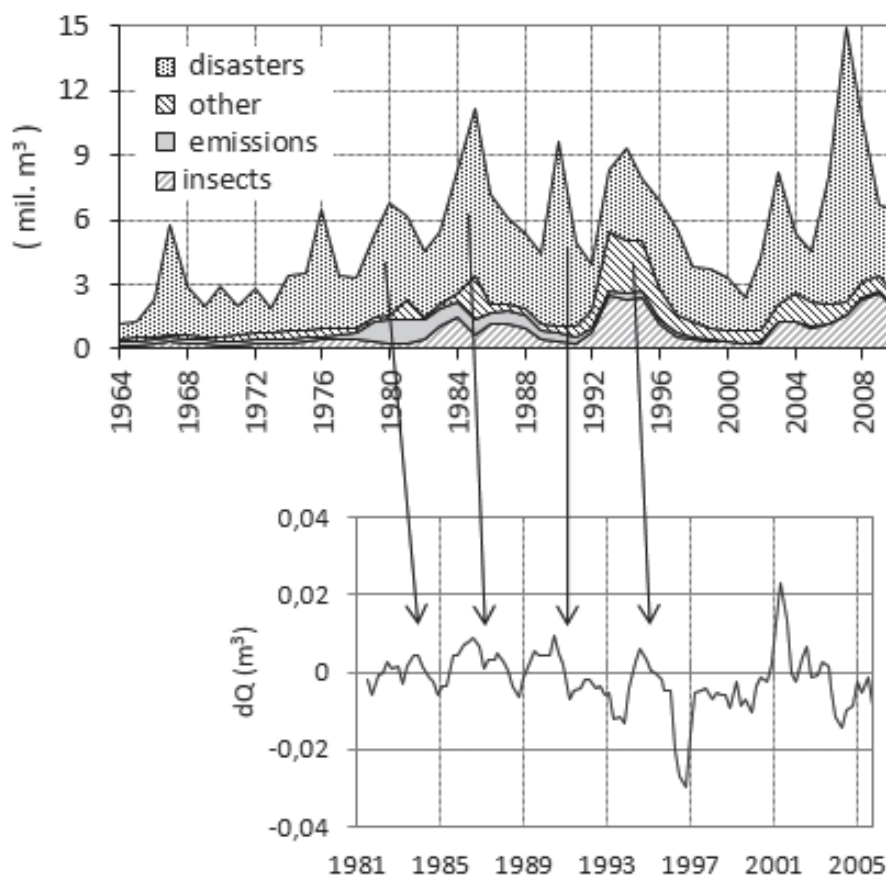

Figure 2. The flow differences $d Q=\left(Q_{\text {obs }}-Q_{\text {sim }}\right)$ in the deforested Uhlí ská River and the Lenora River with some agricultural activity - in comparison with disasters in forests in the Czech Republic.

Figura 2. Las diferencias de caudal $d Q=\left(Q_{o b s}-Q_{\text {sim }}\right)$ en la zona deforestada del río Uhlí ská y el río Lenora con cierta actividad agraria - en comparación con desastres de los bosque en la República Checa.

more water for total water supply (Jewitt et al., 2004). Modelling of the rainfall-runoff process used in the 

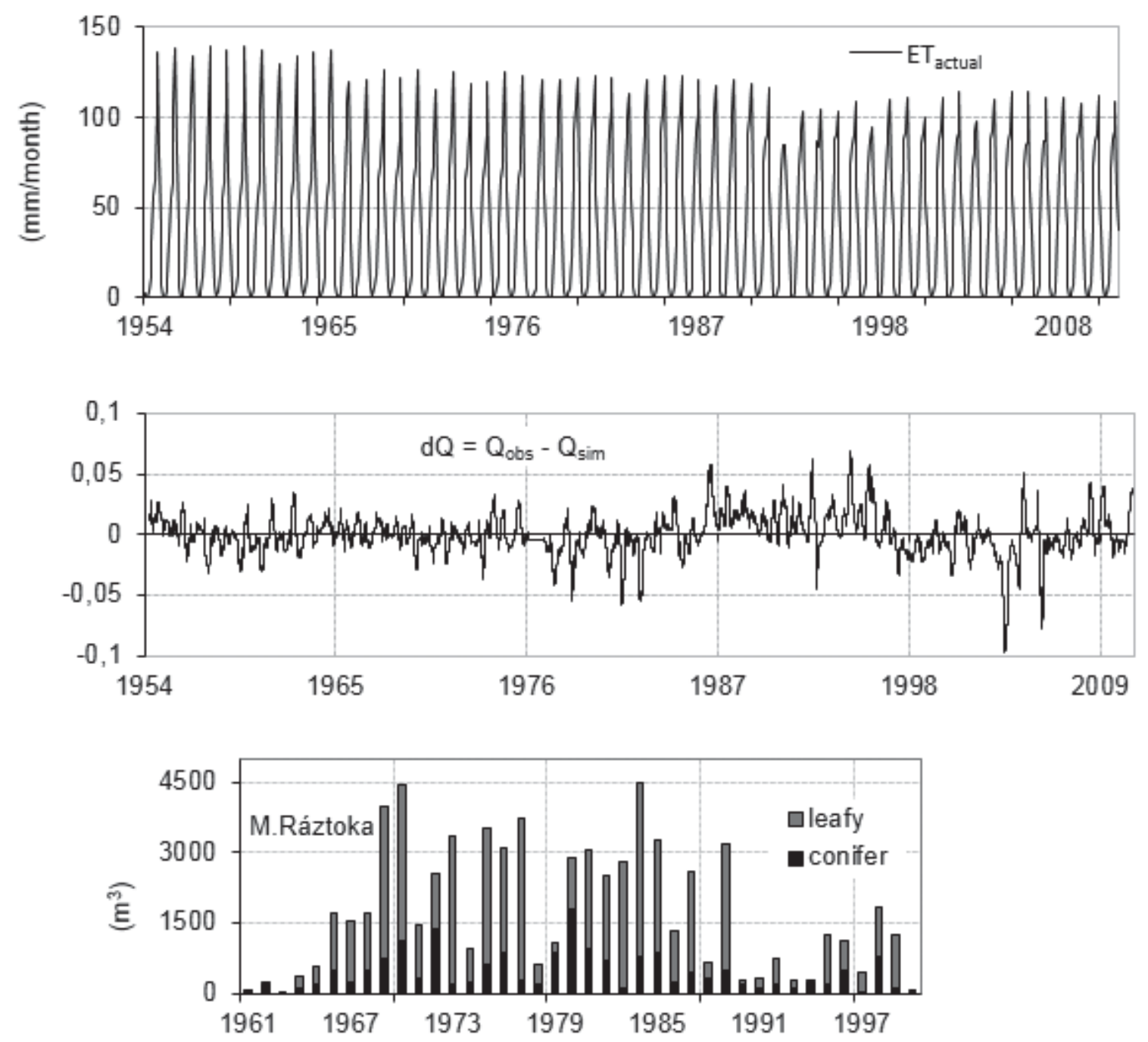

Figure 3. Evapotranspiration in the Ráztoka basin as the output of modelling and deviations ( $\left.d Q=Q_{o b s}-Q_{\text {sim }}\right)$, compared with wood extraction.

Figura 3. Evapotranspiración en la cuenca Ráztoka como salida del modelado y desviaciones (dQ $=Q_{o b s}-Q_{\text {sim }}$ ), comparado con la extracción de madera.

presented experiments provides the possibility of discovering the diverse flow changes in the simulations (Merz, 2006). These changes influence the evapotranspiration demands and consequently the complex water regime (Kuczera, 1997).

\section{Data and approaches used in analyses}

The first step is to prepare the input data for longterm series, which provides data for variously covered and extensive basins. The model inputs include temperatures, precipitation and observed discharges. The input data are in the form of time series with the interval of one day. Hourly intervals are used for flash floods (Kunkel, 2002). The evapotranspiration values are denoted by $E T_{\text {demand. It represents the inputs for }}$ rainfall-runoff modelling. The daily evapotranspiration value is determined by interpolating 12 values that are defined for each month of an annual cycle. The outputs of the simulation are another similar series $\left(\mathrm{ET}_{\text {actual }}\right)$ and are displayed in several graphs in numerous time scales.

\section{Basic attributes of time series analysis}

Time series for the Czech part of Elbe River basin (area of $51,000 \mathrm{~km}^{2}$ ) have been at the disposal for modelling of the rainfall-runoff process, which is 
longer than 100 years. The observations of groundwater level have also been available for nearly 100 years near the Banin locality. This may reveal the advantageous view on the possible fluctuation assessment in (Fig. 4). However, the outputs of the simulation for these large catchments are complemented with the results from hilly and forested exper- imental basins, Raztoka (area of $2.1 \mathrm{~km}^{2}$ ) and Liz (area of $\left.1 \mathrm{~km}^{2}\right)$. The basins are in the regions near the state borders of the country with significant annual snow deposits. The time series available for the modelling has been nearly 60 and 40 years long and the verification had already been prepared (Buchtele andTesar, 2013).
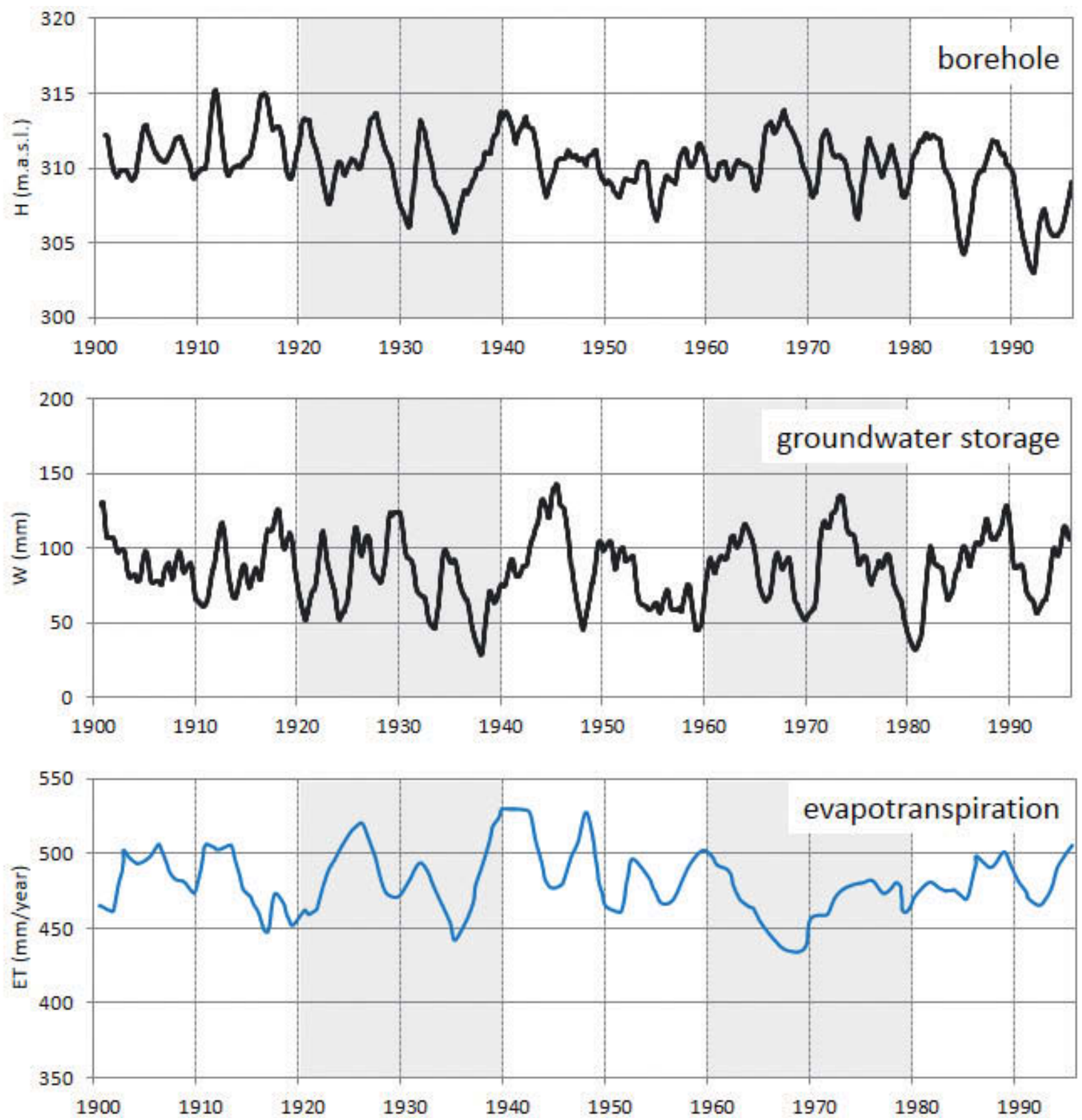

Figure 4. Fluctuation of the monitored water level in the borehole of simulated groundwater storage and evapotranspiration in the Elbe River basin.

Figura 4. Fluctuacion del nivel de agua monitorizado en el sondeo de simulación del almacenamiento de agua subterránea y evapotranspiración en la cuenca del río Elba. 


\section{Optimisation of model calibration}

The genetic algorithm is a heuristic process which uses the principle of the evolution. There are fundamental processes inspired by the evolution (Gilli, 2004). This algorithm is used to find an optimal parameter configuration of the SAC-SMA model (Chlumecky, 2013).

In the initial step, it is necessary to calibrate the model manually because hydrological knowledge and experience are crucial. The resulting manual calibration is the initial calibration which is the input of the optimisation algorithm (Winker, 2004). The optimisation algorithm improves the initial calibration on the base of root-mean-square error (RMSE) (Vrugt et al., 2003), which defines differences between simulated and observed values (Hyndman and Kohler, 2006):

$$
\operatorname{RMSE}(\eta)=\sqrt{\sum_{l=1}^{\eta}\left(S_{l}-Q_{l}\right)^{2} \cdot \frac{1}{|\eta|}}
$$

where: $S$ is the simulated daily discharge, $Q$ is the observed daily discharge and $\eta$ is the length of the input time series.

\section{The output data}

The output is a time series including: simulated discharges $\left(\mathrm{Q}_{\text {sim }}\right)$, demand evapotranspiration $\left(\mathrm{ET}_{\text {demand }}\right)$ and actual evapotranspiration $\left(\mathrm{ET}_{\text {actual }}\right)$. The resulting time series $\eta$ satisfies a property (2), which is defined as follows:

$$
\eta_{\min }=\min \left\{\operatorname{RMSE}\left(\eta_{1}\right), \operatorname{RMSE}\left(\eta_{2}\right), \ldots, \operatorname{RMSE}\left(\eta_{n}\right)\right\} ; \eta_{i} \in S
$$

where: $S$ is the set of all available model calibrations for $i=1 \ldots \eta$, where $\eta$ is defined as the cardinality of set $S$.

\section{Results of rainfall-runoff model implementation}

Diverse aspects of runoff changes due to the climatic fluctuations could partially be explained with the implementation of modelling. Differences between observed and simulated runoff $\left(\mathrm{dQ}=\mathrm{Q}_{\text {obs }}-\mathrm{Q}_{\text {sim }}\right)$ have been used to evaluate the fluctuations or tendencies in the water regime. The complete results of rainfallrunoff simulations are included here. The differences between monitored and simulated flows have also been presented recently. This approach implemented in the whole context means that the modelling out- puts represent the resulting evapotranspiration $\left(E T_{\text {demand }}\right)$. The real values of the evapotranspiration are obtained with great difficulty by monitoring, e.g. from other meteo-observations, and might exceptionally be available.

The significant development of the evapotranspiration is shown in (Fig. 3) and is the illustration of the situation in the forested catchment, where the deforestation has been carried out during the monitored period, and young trees have consecutively appeared in the following decades. The resulting actual evapotranspiration exhibits clear tendencies. This is the response to the conditions of trees, including those of afforestation. The remaining deviations $(\Delta \mathrm{Q}=$ $\left.\mathrm{Q}_{\text {obs }}-\mathrm{Q}_{\text {sim }}\right)$, after the precision of $\mathrm{ET}_{\text {actual, }}$ could still be caused by the mechanical movements of the trees. The modelling for the Ráztoka basin in Beskydy Mts. provides the data in the graphs in Figure 3.

The variability in the long-term time series and the view on the fluctuations of groundwater storage are explicitly illustrated in Figure 4. One part of the chart is the simulated volume of water in the state variable LZFPC (Lower Zone Free Primary Content) of SACSMA model for the Czech Elbe River. The other chart presents the water level of the borehole located in the Cretaceous area near the border of the Elbe River basin. The fluctuation seems to confirm the existence of oscillations and partly a credibility of these quantities, i.e. from the calibration of the rainfall-runoff model.

Figure 5 presents the differences between observed discharges $\left(\mathrm{Q}_{\text {obs }}\right)$ and simulated daily flows $\left(Q_{\text {sim }}\right)$. This is an example of the length of series for the evaluation of $E T_{\text {demand }}$ and the resulting $E T_{\text {actual, }}$ The figure summarises and submits the outputs from several arrangements of rainfall-runoff modelling. The outputs could document the remarkable situations in runoff processes, i.e. the phenomena requiring the attention of water users.

The simulated groundwater volumes in LZFPC and the outflows of two springs are also presented in Figure 6. This is the status in the upper part of the VItava River basin with diverse crystalline bedrocks. The groundwater storage contains a significant part of water balance even under such conditions as this example shows.

Figure 6 presents the simulated course of the value of groundwater storage as the source of water for evapotranspiration. It also illustrates the possible abrupt changes of water storages levels and has a decreasing tendency by spring. The trend is probably a consequence of a growing forest in the adjacent forest area. Some abrupt changes in runoff and $E_{\text {actual }}$ may be caused by wind devastation of the forest. 

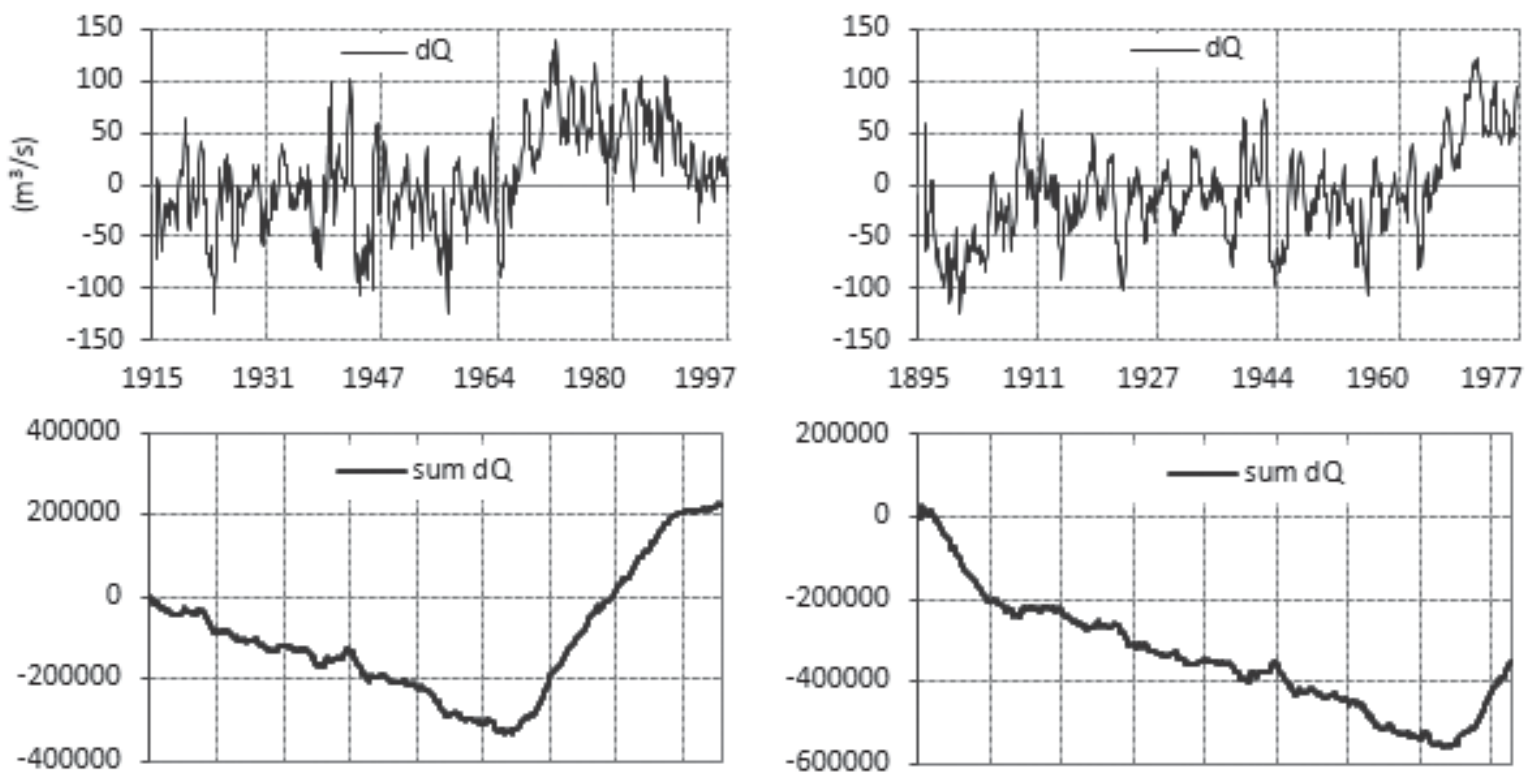

Figure 5. The time series of differences between observed and simulated long-term discharge of the Elbe River from unequal intervals, i. e. for diverse optimised periods.

Figura 5. Series temporales a largo plazo de diferencias entre descarga simulada y observada para el río Elba a partir de intervalos irregulares, esto es, para diversos períodos optimizados.

The fluctuations mentioned above in Figure 2 appeared as unexpected repeated events in the Uhlí ská basin. Mostly this is a response to natural forest damage, e.g. by wind and insect disasters. These cases are considered random situations and phenomena. They are a consequence of natural climatic fluctuations that correlate with the above mentioned wind disasters and very significant acid rain caused by nearby thermal power plants.

The modelling of rainfall-runoff process is mainly used as a tool in the affirmation of actual evapotranspiration activity. The process is visible for the Elbe River catchment in Figure 7 and it could be considered as a nearly stable process in a long-term period. A similar attribute is also valid for the differences between the assumed evapotranspiration demand $\left(E T_{\text {demand }}\right)$ and the actual evapotranspiration $\left(E T_{\text {actual }}\right)$, i.e. $d E T=E T_{\text {demand }}-E T_{\text {actual }}$ which are in the lower graph. The semilogarithmic scale clearly shows that this quantity appears as the phenomenon with apparent annual and long-term variability.

However, the presented results are the outputs that also include the period of 1895-1915. The relatively large system of weirs was mostly built during this time for ship transport.

The construction affects the different courses in the two parts of Figure 5. It shows the distinctive differences $\mathrm{dQ}=($ Qobs - Qsim) in the period mentioned above. It is obtained from the calibration of the rain- fall-runoff model and the optimisation of model parameters. The disparate tendency indicates the visible land-use activity.

The average monthly evapotranspiration for several periods of time shows a surprising view of the annual cycle of the monthly evaporation amounts. The ascertaining of the values of evapotranspiration simultaneously with the optimisation of model parameters could be a promising approach when qualities such as precision are desirable. The further part of Figure 8 presents the values of $E T_{\text {demand }}$ in the distinct forms in the next part (b) and the corresponding values are diversely appointed.

Figure 9 shows the comparison of obtained actual evapotranspiration values in an annual cycle for the large basin of the Elbe River and the experimental catchment Liz. It could be an indication to study the evapotranspiration in water consumption further.

The vegetation activity probably causes the differences in consumption during the different parts of warmer periods of the year. This activity corresponds to the agricultural production response in water balance at regional scales, as mentioned in (Brown, 1997).

Floods, as frequently unexpected situations, require flexible data applicable for improvements of certain parameters for rainfall-runoff modelling. It is firstly connected with fundamental land-use changes. In this context, the automatic identification of model 

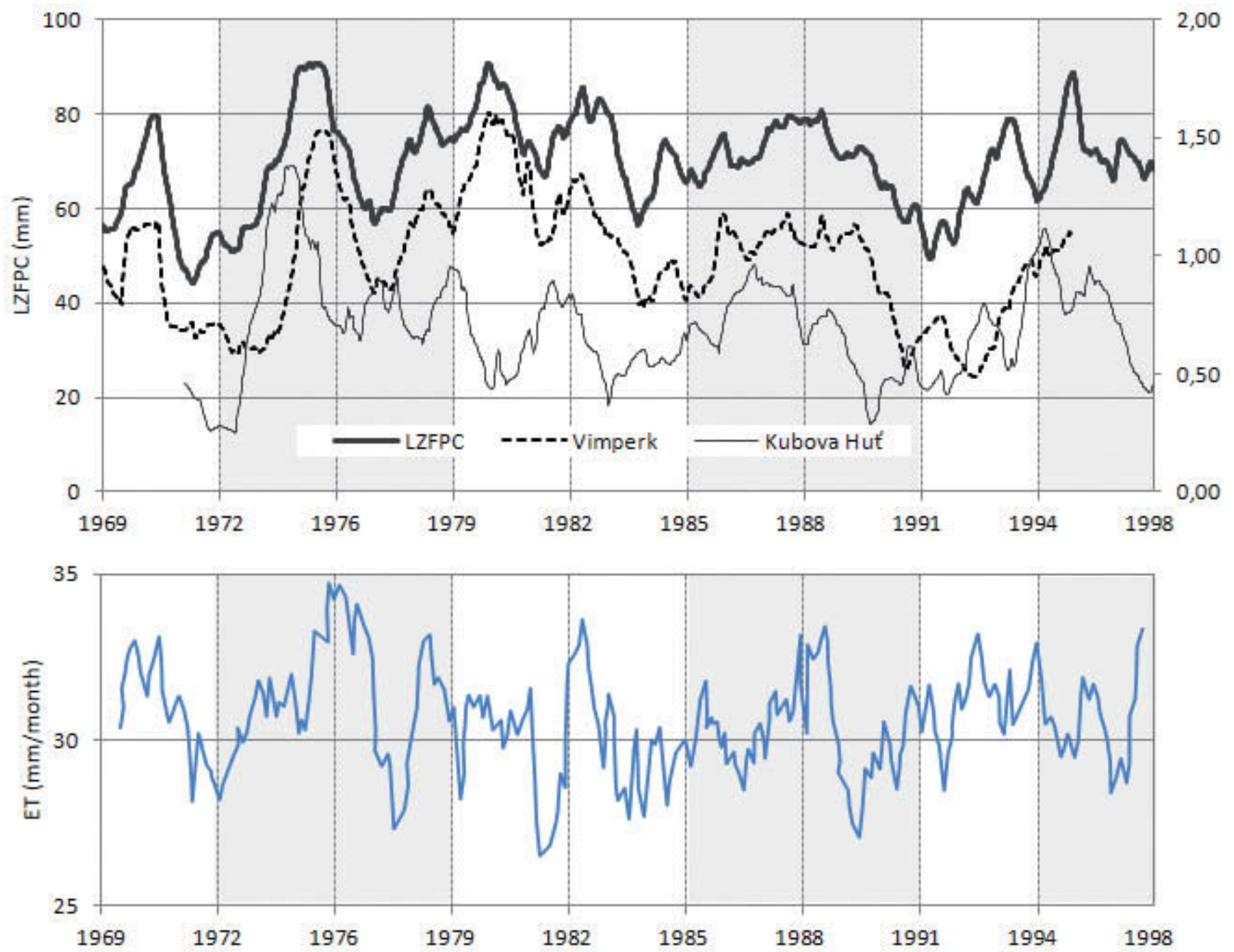

Figure 6. The simulated groundwater storage and the outflows of springs in the Šumava Mts and evapotranspiration in the upper VItava River basin.

Figura 6. El almacenamiento de agua subterránea simulado y las descargas de los manantiales en las montañas Šumava y la evapotranspiración en la cuenca alta del río Vltava.

parameters is illustrated in Figure 10. This is the example in which the manual calibration of the model could be improved. The starting point for implementation of automatic identification of parameters has been favourably accomplished. Figure 11 moreover indicates that events anticipated in the context with vegetation cover may not be the reason for the changes in evapotranspiration, but rather for the changes in the parameters of the conceptual model. The main SAC-SMA parameters provided in Figure 11 are briefly described in Table 1.

The repeating and seemingly random frequent fluctuations require attention in the framework of modelling. The monitoring services and the users of existing data sets have to take into account the possi- ble uncertainty for interpretation of monitoring results.

\section{Conclusions}

The evolution of vegetation is usually expected to be one of the natural causes for the annual fluctuations in water resources. The significant reason for these annual fluctuations may also be its development in scale over the decades. This affects long-term evapotranspiration variability, also caused by massive wind disasters, which damage forests in the vegetation cover, and/or even the increased amount of wood volumes in the forests. One of the three evaluated basins 
M. Chlumecky, et al., 2018. Ascertaining evapotranspiration series by the optimized... Boletín Geológico y Minero, 129 (3): $487-497$
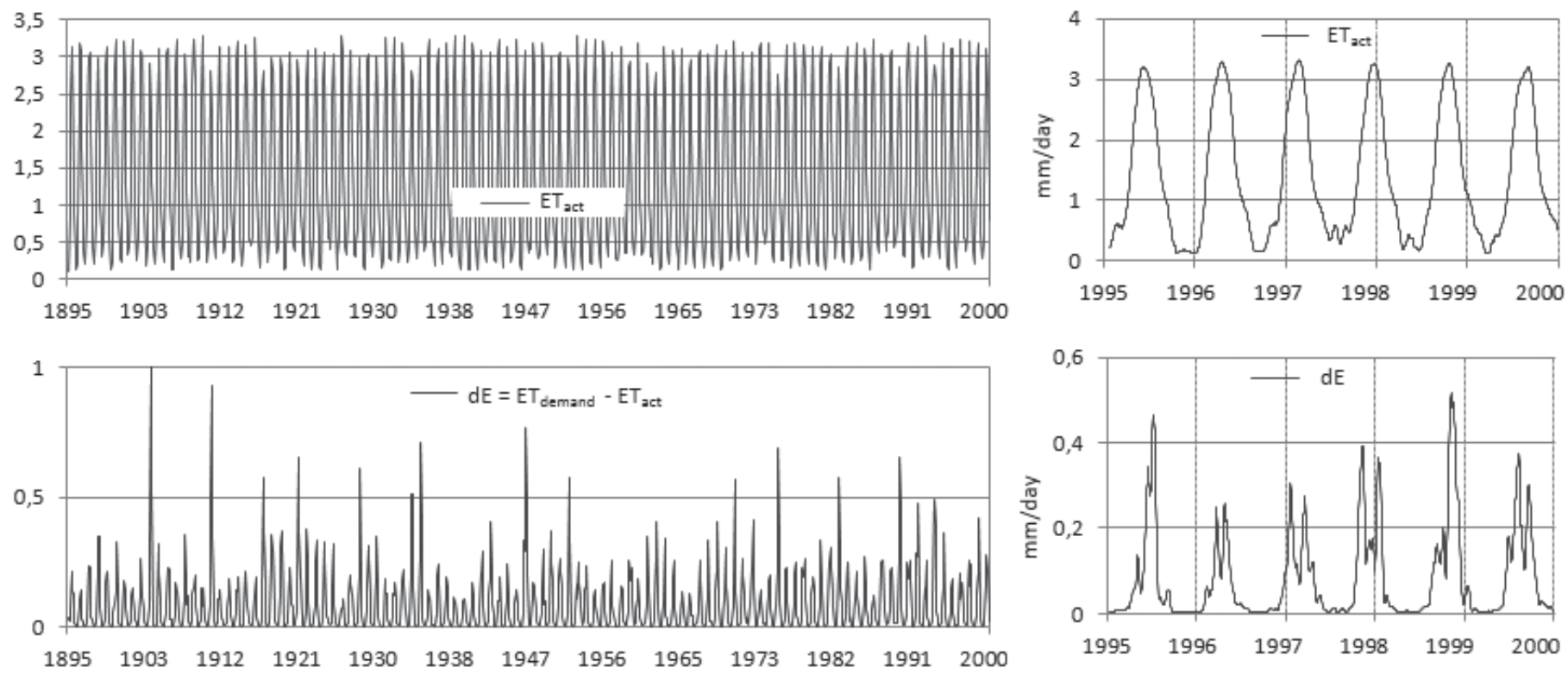

Figure 7. Actual evapotranspiration in the Elbe River basin and its disparity with $\mathrm{ET}_{\text {demand. }}$. Figura 7. Evapotranspiración real en la cuenca del río Elba y su diferencia con $E T_{\text {demand }}$
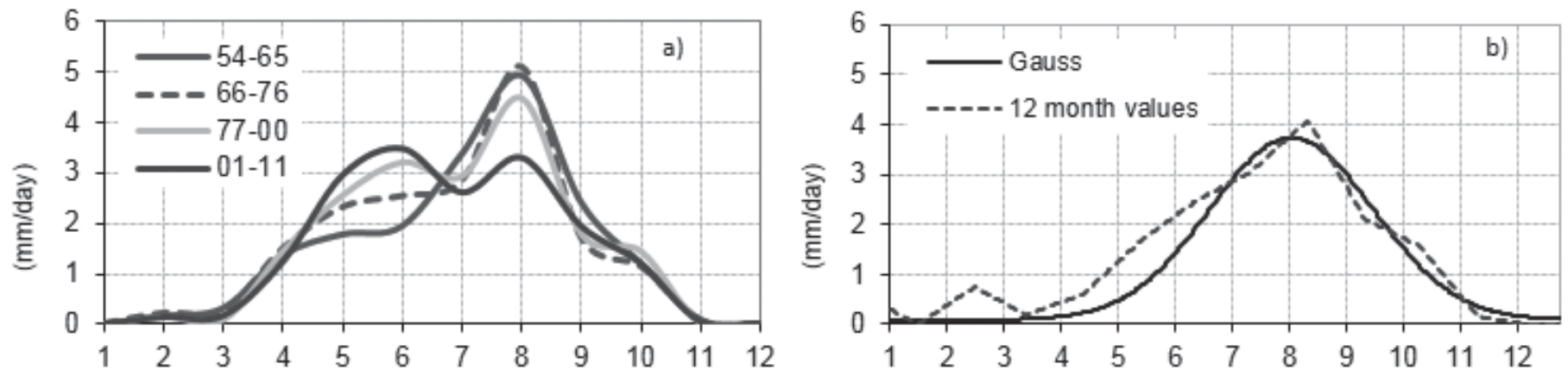

Figure 8. a) Monthly averages of $\mathrm{ET}_{\text {actual }}$ for Liz basin during several periods. b) Two distinct assumed evapotranspiration demand (ET demand) in Ráztoka basin.

Figura 8. a) Medias mensuales de ET actual para la cuenca Liz durante varios períodos. b) Dos demandas distintivas de evapotranspiración ( $\left.E T_{\text {demand }}\right)$ en la cuenca Ráztoka.

\begin{tabular}{|l|l|}
\hline Parameter & Description \\
\hline ZPERC & Maximum percolation rate coefficient \\
\hline LZTWM & Lower zone tension water capacity $(\mathrm{mm})$ \\
\hline LZFSM & Lower zone supplemental free water capacity $(\mathrm{mm})$ \\
\hline LZFPM & Lower zone primary free water capacity $(\mathrm{mm})$ \\
\hline UZTWM & Upper zone tension water capacity $(\mathrm{mm})$ \\
\hline UZFWM & Upper zone free water capacity $(\mathrm{mm})$ \\
\hline
\end{tabular}

Table 1. Description of significant SAC-SMA model parameters.

Tabla 1. Descripción de los parámetros más importantes del modeIo SAC-SMA. with forest cover has been gradually reforested. The water regime was restored and the results correspond to the model output.

The modelling of the rainfall-runoff process appears helpful in the efforts to minimise uncertainties in the water regime caused by the regularly appearing natural fluctuations and/or by the seemingly random abrupt changes. The disparities between observed and simulated discharges are helpful in evaluating the variability of both actual changes. It also enables identification of intervals for which the demand of evapotranspiration could be expected as the stable process. Then a model imple- 

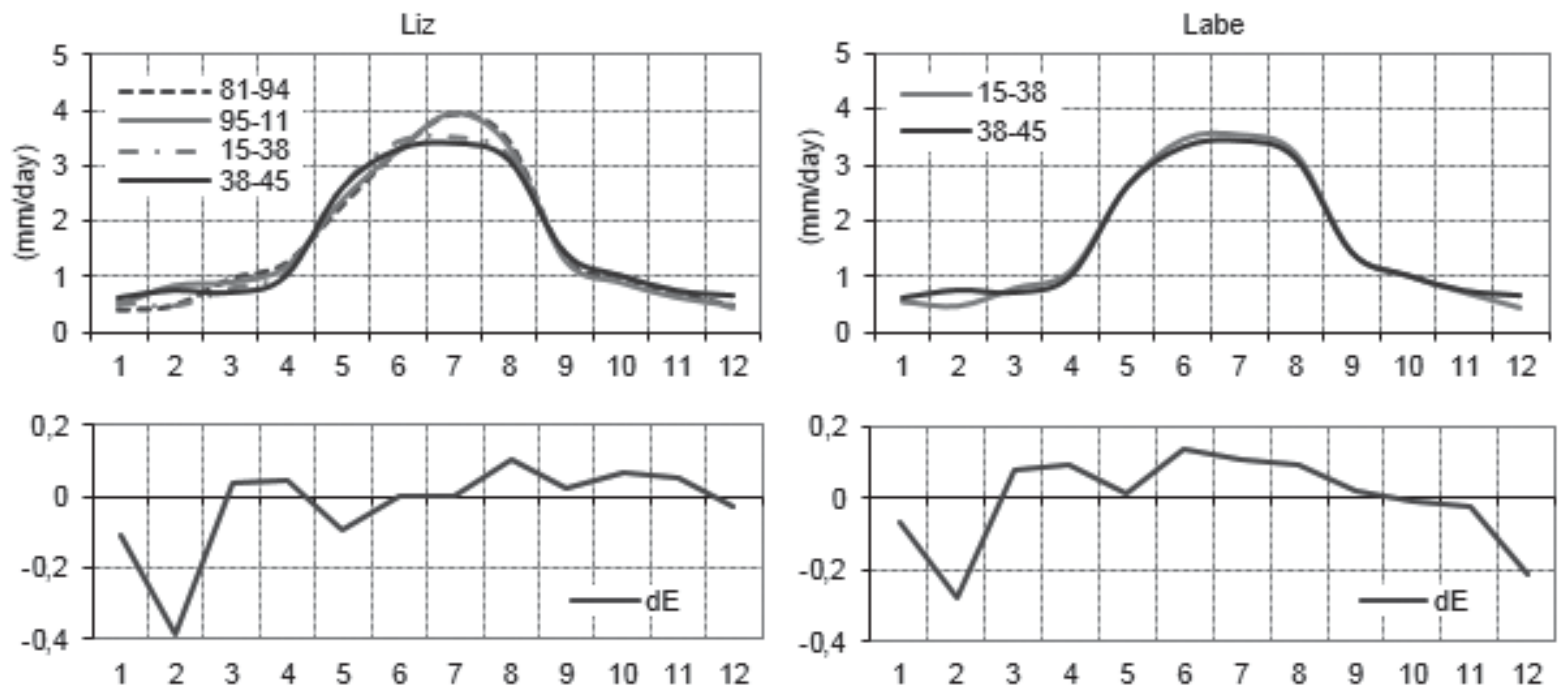

Figure 9. The annual course of actual evapotranspiration and the differences between two periods in the small forested Liz basin and the large Elbe River.

Figura 9. La evolución anual de la evapotranspiración real y las diferencias entre dos períodos en la pequeña cuenca deforestada de Liz y la gran cuenca del río Elba.

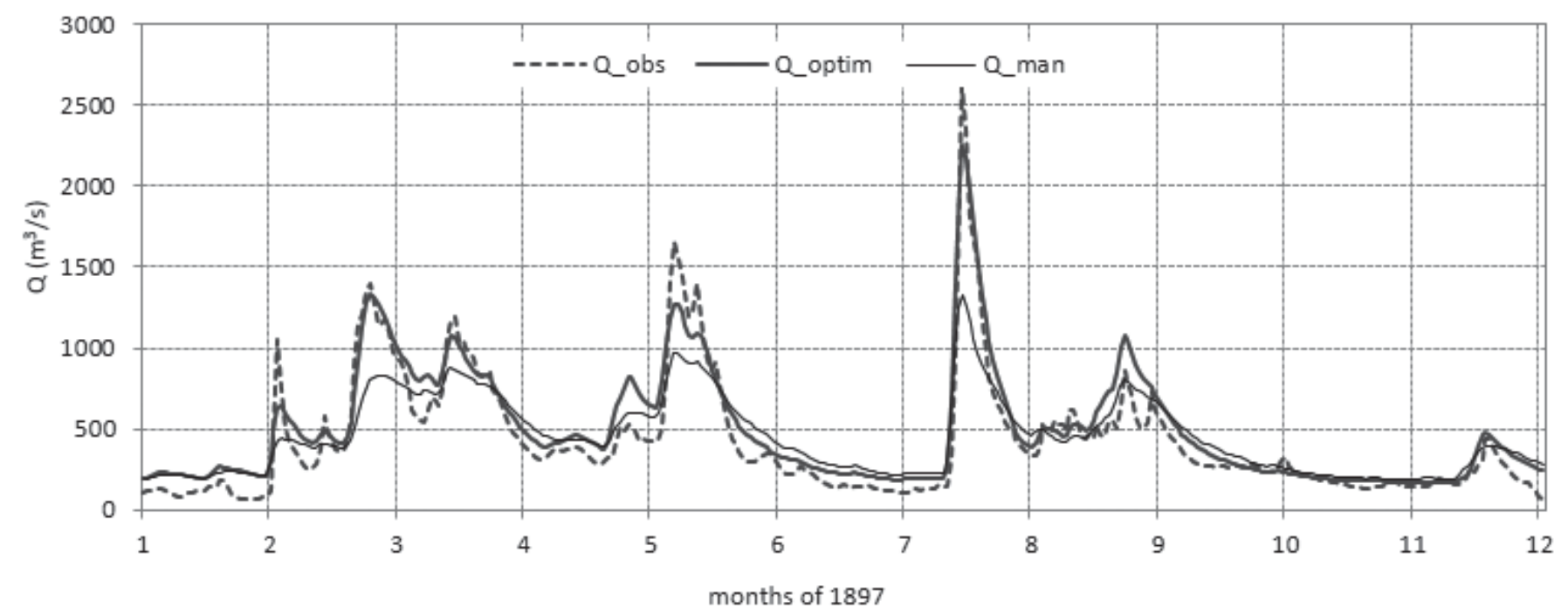

Figure 10. Accuracy of discharge simulation with manual calibration of rainfall-runoff model and after optimisation of parameters for the Elbe River.

Figura 10. Precisión de la descarga simulada para el río Elba, con calibrado manual del modelo de precipitación-escorrentía y después de la optimización de los parámetros.

mentation and an optimal simulation could be reached.

Optimisation process used in this context appears as the efficient tool to evaluate decreased or increased values of evapotranspiration. Monthly values of RMSE (root mean square error) have been used as the validation criterion in the adjusted genetic algorithm. This criterion provides the best results for the observed watersheds. The model implementa- tion and the simulations, with optimal values of the model parameters and of the evapotranspiration, could be achieved for partial time intervals within the whole period. In this context, the changes in vegetation cover and the resulting altered evapotranspiration can be connected to the infiltrations meaning that the model parameters can have other values for different periods after optimisation, and this has mainly been observed in basins with reforestation. 

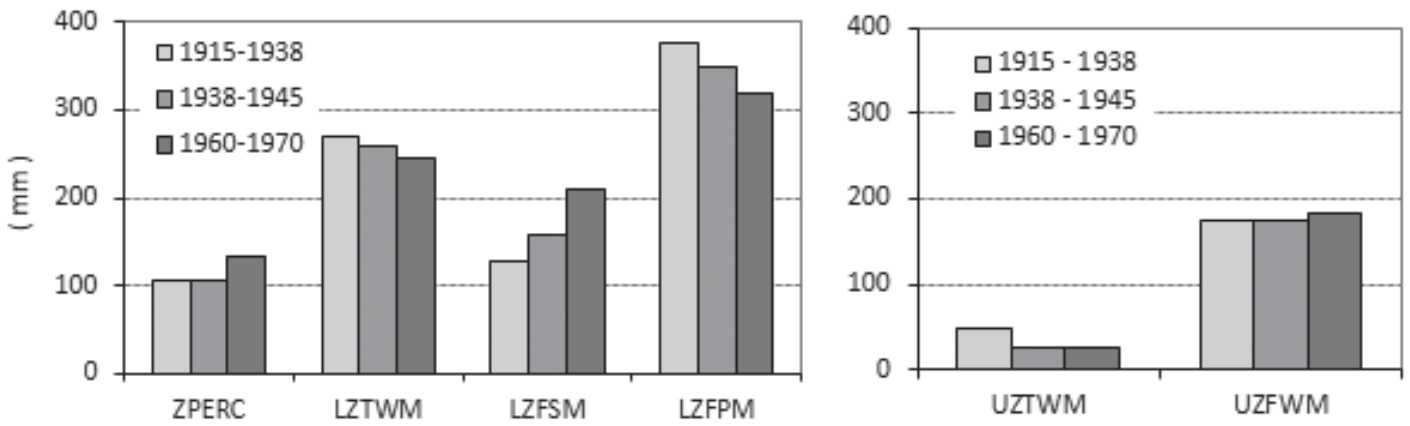

Figure 11. Optimised parameters in different periods for the Elbe River for SAC-SMA model.

Figura 11. Parámetros optimizados en diferentes períodos para el modelo SCA-SMA del río Elba.

\section{Acknowledgements}

This work was supported by the Grant Agency of the Czech Technical University in Prague, grant "Automatic calibration of hydrological models by optimisation algorithms" No. SGS SGS16/091/ $\mathrm{OHK} 3 / 1 \mathrm{~T} / 1$

\section{References}

Beer, J. 2005. Solar variability and climate change. Memorie-Società Astronomica Italiana, 76 (4), 751.

Brown, T. 1997. Clearances and clearings: deforestation in Mesolithic/Neolithic Britain. Oxford Journal of Archaeology, 16 (2), 133-146.

Buchtele, J. and Koskova, R. 2008. Approaches to credible identification of reliable parameters in rainfall-runoff model from long time series. HydroPredict'2008, Prague, 241-244.

Buchtele, J. and Tesar, M. 2013. Influence of the vegetation cover development at the water regime from surface and groundwater storages. Water Managment, 8, 34-39.

Burnash, R. and Ferral, R. 1973. A generalized streamflow simulation system. Conceptual modeling for digital computers. National Weather Service, 134 pp.

Gilli, M. 2004. An Introduction to Optimization Heuristics. In: Department of Econometrics, University of Geneva and FAME, Seminar University of Cyprus.

Hurst, H.E. 1951. Long-term storage capacity of reservoirs. Transactions of the American Society of Civil Engineers, 116 (2), 770-799.

Hyndman, R. J., and Koehler, A. B. 2006. Another look at measures of forecast accuracy. International Journal of Forecasting, 22 (4), 679-688.

Chlumecky, M. 2013. Optimizing of parameters in model (SAC-SMA). POSTER 2013 - 17th International Student Conference on Electrical Engineering. Prague, 1-6
Jewitt, G.P.W., Garratt, J.A., Calder, I.R. 2004. Water resources planning and modelling tools for the assessment of land use change in the Luvuvhu Catchment. Physics and Chemistry of the Earth, 29 (15), 1233-1241.

Koren, V. I., Finnerty, B. D., Schaake, J. C., Smith, M. B., Seo, D. J. and Duan, Q.Y. 1999. Scale dependencies of hydrologic models to spatial variability of precipitation. Journal of Hydrology, 217 (3), 285-302.

Kuczera, G. 1997. Efficient subspace probabilistic parameter optimization for catchment models. Water Resources Research, 33, 177-185.

Kundzewicz, Z.W. 2007. Prediction in ungauged basins - a systemic perspective. Predictions in ungauged basins, Brasilia, 309, 38-47.

Kunkel, R. and Wendland, F. 2002. The GROWA98 model for water balance analysis in large river basins - the river Elbe case study. Journal of Hydrology, 259, 152-162

Leprieur, C., Kerr, Y.H., Mastorchio, S. 2000. Monitoring vegetation cover across semi-arid regions: comparison of remote observations from various scales. International Journal of Remote Sensing, 21(2), 281-300.

Merz, R., Blöschl, G., Parajka J. 2006. Regionalization methods in rainfall-runoff modelling using large catchment samples. IAHS publication, 307, 117.

Vicente-Serrano, S. M., Beguería, S. and López-Moreno, J. I. 2010. A multiscalar drought index sensitive to global warming: the standardized precipitation evapotranspiration index. Journal of Climate, 23 (7), 1696-1718

Vrugt, J. A., Gupta, H. V., Bastidas, L. A., Bouten, W. and Sorooshian, S. 2003. Effective and efficient algorithm for multiobjective optimization of hydrologic models. Water Resources Research, 39 (8), 1214

Wagener, T., Wheater, H. S. and Gupta, H. V. 2004. Rainfallrunoff modelling in gauged and ungauged catchments. Imperial College Press, London, 306pp.

Winker, P. and Gilli, M. 2004. Applications of optimization heuristics to estimation and modelling problems. Computational Statistics \& Data Analysis, 47 (2), 211-223

Recibido: septiembre 2016

Revisado: diciembre 2016

Aceptado: enero 2017

Publicado: septiembre 2018 